\title{
Evaluation of pharmacological activities, cytotoxicity and phenolic composition of four Maytenus species used in southern African traditional medicine to treat intestinal infections and diarrhoeal diseases
}

\author{
Aroke Shahid Ahmed ${ }^{1,2}$, Lyndy J McGaw ${ }^{1}$ and Jacobus N Eloff ${ }^{*}$
}

\begin{abstract}
Background: Microbial infections and resulting inflammation and oxidative stress are common pathogenesis of gastrointestinal tract (GIT) disorders. In South Africa, several species of the genus Maytenus are used in traditional medicine to treat various infectious diseases. Most of the previous work on this genus was focused on nonpolar extracts from the root and bark. In this study, leaf extracts of polar extracts of Maytenus peduncularis, Maytenus procumbens, Maytenus senegalensis and Maytenus undata were evaluated for antimicrobial, anti-inflammatory and antioxidant activities to determine their efficacy as therapeutic agents in GIT disorders.

Methods: Phenolic-enriched leaf extracts and fractions were prepared by extracting with acidified $70 \%$ methanol and solvent-solvent fractionation. The activities of the fractions against Staphylococcus aureus, Pseudomonas aeruginosa, Escherichia coli and Enterococcus faecalis as well as clinical isolates of Aspergillus fumigatus, Candida albicans and Cryptococcus neoformans were determined using a serial microplate dilution method. Antioxidant activities were determined using 1,1-diphenyl-2-picrylhydrazyl (DPPH), 2,2'-azinobis(3-ethylbenzthiazoline-6sulphonic acid) (ABTS), hydroxyl $(\mathrm{OH})$ radical scavenging and linoleic acid peroxidation inhibitory assays. The phenolic composition as well as the cytotoxicity against Vero cell lines of the crude extracts was evaluated using various standard protocols.

Results: The antimicrobial activities were concentrated in the non-polar fractions of hexane, dichloromethane and ethyl acetate (MICs 19-312 $\mu \mathrm{g} / \mathrm{ml}$ ). The crude extracts and polar fractions (butanol and water) had moderate to poor antimicrobial activity (MICs 312 to above $2500 \mu \mathrm{g} / \mathrm{ml}$ ). The crude extracts and polar fractions had good antioxidant activity ( $E_{50}$ values varied from 1.22 to $607 \mu \mathrm{g} / \mathrm{ml}, 1.71$ to $312 \mu \mathrm{g} / \mathrm{ml}$ and 23 to $284 \mu \mathrm{g} / \mathrm{ml}$ for DPPH, $\mathrm{ABTS}$ and $\mathrm{OH}$ respectively. Linoleic acid peroxidation inhibition $\mathrm{EC}_{50}$ values of the crude extracts ranged between 27 and $39 \mu \mathrm{g} / \mathrm{ml}$ with relatively low toxicity against Vero cell lines $\left({ }^{2} C_{50}\right.$ values 87 to $\left.187 \mu \mathrm{g} / \mathrm{ml}\right)$. Fractionation of a crude extract with low activity could lead to fractions with more potent activity.

(Continued on next page)
\end{abstract}

\footnotetext{
* Correspondence: kobus.eloff@up.ac.za

${ }^{1}$ Phytomedicine Programme, Department of Paraclinical Sciences, Faculty of Veterinary Science, University of Pretoria, Private Bag X04, Onderstepoort 0110, South Africa

Full list of author information is available at the end of the article
} 


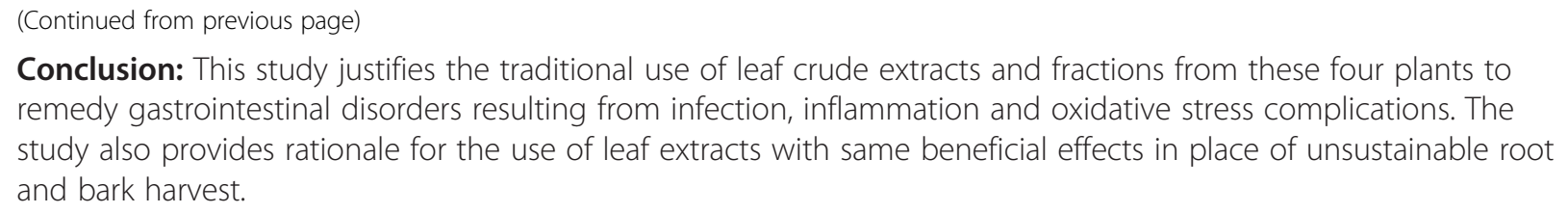
remedy gastrointestinal disorders resulting from infection, inflammation and oxidative stress complications. The study also provides rationale for the use of leaf extracts with same beneficial effects in place of unsustainable root and bark harvest.

Keywords: Maytenus, Gastrointestinal tract, Infections, Diarrhoea, Cytotoxicity

\section{Background}

The gastrointestinal tract (GIT) is a long tube with huge epithelial surface area through which nutrients and fluid passes for digestion and absorption [1]. The basic sequence of GIT is mouth, oesophagus, stomach, duodenum, small intestine, large intestine, rectum, and the anus, where wastes are eliminated [2]. A healthy GIT is permanently populated with a diverse microbial community, termed the microbiota, which is composed of over 300 different species of prokaryotic and eukaryotic microorganisms. The microbiota microbes exist in complex commensal relationships within the host environment, including the mucosa and luminal contents of the digestive tract $[3,4]$. Infection of the GIT by pathogenic or opportunistic (intestinal microbiota) microbes cause a variety of intestinal disorders. The disorders may lead to nausea, vomiting, diarrhoea, abdominal pain, intestinal inflammation, bloating and flatulence, or systemic diseases [5]. GIT infectious pathogens (bacteria, virus, protozoa and rarely fungi) have a multitude of proven and hypothetical mechanisms through which they can induce various ailments.

Among the GIT disorders, diarrhoea is the most prevalent and dangerous being a major cause of morbidity and mortality worldwide [5]. Diarrhoea occurs when secretory processes exceed the absorptive capacity of the GIT through four identifiable mechanisms: (1) increased secretion from mucosal; (2) decreased absorption (ions and/or solutes and water); (3) altered motility; and (4) increased permeability [6]. The flushing action of diarrhoea can be beneficial as it leads to removal of harmful luminal contents, however, the resulting dehydration from uncontrolled episode can become life threatening [4]. Mortality from infectious diseases in developed countries, where there are low records of invasive infection is low while in resource-constrained developing countries with more cases of infective ailments, the death rate is high [7]. High prevalence of infectious diarrhoea in resourceconstrained countries where most people with immunodeficiency challenges live is associated with high poverty, illiteracy level, lack of portable water, poor sanitation, unhygienic conditions, and inadequate control of vectors and infection of reservoirs [8]. Diarrhoea caused by a variety of definable pathogens (opportunistic infection) is also a common problem in human immunodeficiency virus (HIV)-infected patients with CD4+ counts $<200$ cells/ $\mu \mathrm{l}$ or patients with advanced human immunodeficiency virus (AIDS) [9]. The emergence multi-drug resistance strains to antibiotics are compounding the problems of treatment of infectious diseases in immunocompromised patients [10].

A harmful stimulus in GIT including endotoxins, infections and cytotoxins stimulates macrophages and monocytes to secrete several pro-inflammatory cytokines such as tumour necrosis factor- $\alpha$, interleukin- 1 , and interleukin-6 [11]. Nonspecific inflammation induced by these irritants can cause intestinal fluid accumulation which may result in inflammatory diarrhoea [4]. Cytotoxic effects on GIT may lead to villus atrophy, decrease in the digestive and absorption capacities of the intestine, generating a malabsorption components. Microbial fermentation of undigested and non-absorbed nutrients reaching the colon, leads to accumulation of osmotically active solutes causing osmotic diarrhoea [7]. Inflamed GIT lead to persistent changes in enteric nervous system, the intrinsic innervation of the bowel which controls virtually all intestinal functions (motility, secretion, blood flow, mucosal growth and aspects of the local immune system), and smooth muscle function. The resultant colonic dysmotility, hypersensitivity, and dysfunction accompany GIT inflammation give rise to diarrhea, cramping, and pain [7].

Cytokines from activate inflammatory cells can release large amounts of toxic oxygen (peroxide anion, hydrogen peroxide and hypochlorous acid) and nitrogen species, proteases, arachidonic acid metabolites (prostaglandins from cyclooxygenase pathways and leukotrienes from lipoxygenase). The processes cause cellular injury by several mechanisms including peroxidation of membrane lipids and oxidative damage of proteins or DNA. The mechanisms of lipid peroxidation involved free radical or other reactive oxygen species chain reactions to produce toxic products which attack and damage biological molecules [11]. Oxidative species are not dormant products of inflammation, but active molecules in the pathogenesis of inflammatory processes. Gastrointestinal infections are potent stimuli of intestinal membrane lipids peroxidation as an important pathogenic 
event in infectious diarrhoea [12]. Increased concentrations of reactive species and depleted inherent antioxidant defences in intestinal mucosa are involved in a cycle of infection, malabsorption, and malnutrition [13]. Superoxide dismutase and catalase are endogenous antiperoxidative enzymes that protect the cellular constituents against oxidative damage. However, the efficacy of the endogenous antioxidant defence system may be impaired during inflammation [14]. High antioxidative activity and efficient inhibition of polyunsaturated fatty acid peroxidation of GIT epithelial lipid by pharmacological agents including phytochemicals can significantly counteracted oxidative stress and inflammation in this common and chronic infectious disease.

Treatment of infectious diarrhoea typically targets the specific pathogen causing the condition. Some therapies that may be used include antimicrobial agents, such as ciprofloxacin (bacterial pathogens), such as amphotericin, fluconazole (fungal pathogens) or antiprotozoal agents, such as metronidazole (Giardia infection) or albendazole (Encephalitozoon intestinalis). Causal pathogens of GIT disorders are becoming resistant to drugs [15-17]. These resistant pathogens have given rise to:

- Infections that would otherwise not have occurred.

- Increased frequency of treatment failures.

- Increased severity of infections [18].

Hence the search for more safe and effective antimicrobial compounds is important. Plant-based medicines have been used for thousands of years in traditional systems of health care to treat a wide range of ailments caused by microbial infections and resultant inflammatory/oxidative stress complications. Search for plants with broad pharmacological activities, but of low toxicity has increasingly gained importance in recent years. In southern Africa, different plants species belonging to the genus Maytenus are extensively used in traditional medicines to treat diarrhoea, stomach infections, pain and inflammation of the digestive system, stomach cleansing, chest pain, and skin diseases. The species include Maytenus accuminata (L.f.) Loes [19], Maytenus heterophylla (Eckl. \& Zeyh) Robson [20], Maytenus peduncularis (Sond) Loes [21], Maytenus procumbens (L.f.) Loes [22], Maytenus undata (Thunb) Blakelock [23] and Maytenus senegalensis (Lam.) Exell (syn Gymnosporia senegalensis (Lam.) Loes) [24-26].

Another important point to consider is that the use of the root or bark stem of trees as medicinal component could compromise the population of the native species. Continuous exploitation of root or bark stem of trees is not sustainable because removal of such parts leads to plant death [23,27]. It is important to verify whether other parts of the plant can have the same beneficial effects with lower toxicity. From the literature, root bark and stem bark of Maytenus are primarily used in traditional medicines and the major focus of previous research on the genus. However, there are reports of various uses for the leaves [23,27]. In the Phytomedicine Programme we evaluated and determined the biological activities of tree leaf extracts for medicinal purposes because of the sustainability of leaf harvest compared to roots and stems.

In this study, we hypothesised that phytochemicals from the leaf extracts of $M$. peduncularis, $M$. procumbens, $M$, undata and $M$. senegalensis may not be be cytotoxic and can provide protection against some enteroinvasive pathogens as well as sustain recovery of the epithelium by promoting inflammatory and oxidative stress healing in infectious diarrhoea. We investigated the rationale for the use of the crude leaf extracts and fractions of various polarities from the four Maytenus species as therapeutic and preventative agents, at least in infectious diarrhoea, and perhaps also in diarrhoea associated with acute or chronic inflammation/oxidative damage of the gut.

\section{Methods \\ Plant collection}

The leaves of $M$. peduncularis, M. procumbens, $M$. senegalensis (syn Gymnosporia senegalensis (Lam.) Loes) and M. undata were collected by courtesy of Mrs Lita Pauw from the samples kept in the Phytomedicine Programme plant collection. The plant material was originally identified and authenticated by Ms. Lorraine Middleton and Magda Nel at the University of Pretoria Botanical Garden. The voucher specimen numbers in the HWG Schweikert Herbarium were PRU 76382, PRU 77119, PRU 114717, and PRU 18576 for $M$. peduncularis, $M$. procumbens, $M$. senegalensis (syn Gymnosporia senegalensis) and $M$ undata respectively.

\section{Preparation of extracts}

The extraction process to obtain crude extracts and fractions with varying polarities is presented in Figure 1 as described by Naczk and Shahidi [28] with some modifications. The ground leaf materials $(20 \mathrm{~g})$ were extracted with mixture of acidified $70 \%$ acetone and n-hexane. The dried polar samples (crude extracts, butanol and residual fractions) were dissolved in $70 \%$ acetone or $25 \%$ methanol in acetone solution while the non-polar (hexane, ethyl acetate, and dichloromethane) fractions were dissolved in acetone for bioassays and phytochemical analysis.

\section{Antimicrobial assays \\ Microbial strains}

Four standard bacterial strains of the most important nosocomial pathogens including two Gram positive 


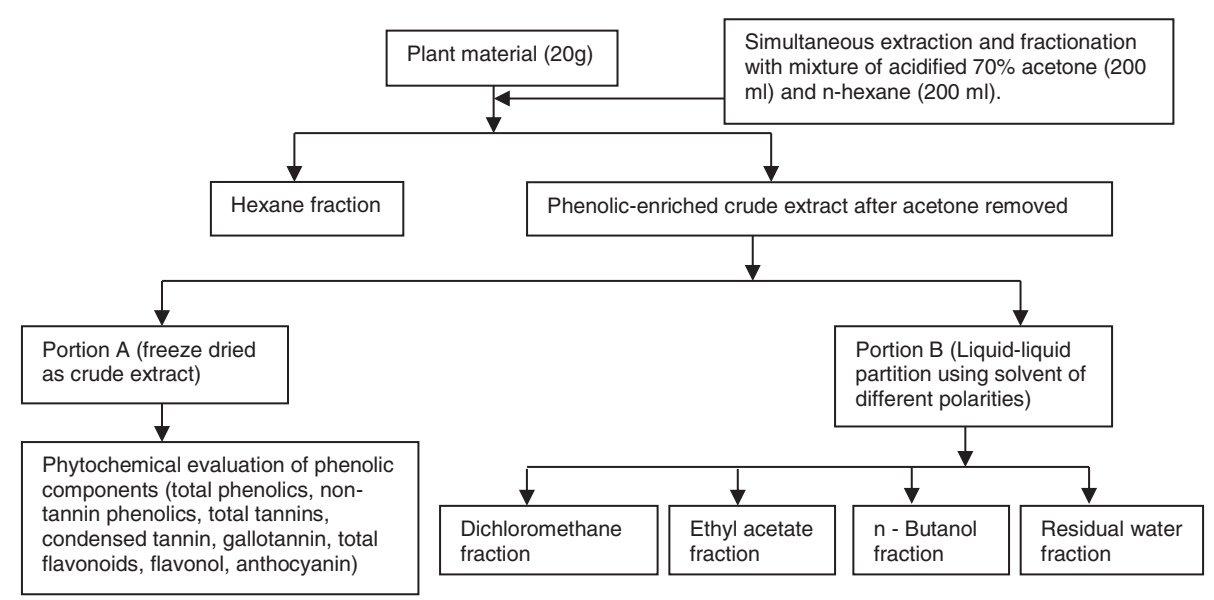

Figure 1 Optimized phenolic-enriched extraction process, fractionation and, analysis of the extract phenolic content.

species (Staphylococcus aureus (ATCC 29213), Enterococcus faecalis (ATCC 29212)), and two Gram negative (Escherichia coli (ATCC 25922), Pseudomonas aeruginosa (ATCC 27853) were used in this work. The bacteria are commonly involved in GIT infections with resultant inflammation and diarrhoeal symptoms [29-31]. Three pathogenic and opportunistic fungal isolates were obtained from the Bacteriology Laboratory, Department of Veterinary Tropical Diseases, Faculty of Veterinary Science, University of Pretoria and used as test organisms. These fungi represent the different morphological forms of fungi, namely yeasts (Candida albicans isolated from a Goldian finch and Cryptococcus neoformans isolated from a cheetah) and moulds (Aspergillus fumigatus isolated from a chicken), all of which suffered from a systemic mycosis. These fungi are the most common and important opportunistic disease-causing fungi of animals mainly urogenital, respiratory and gastrointestinal complications [32-37].

\section{Minimum inhibitory concentration (MIC)}

Minimum inhibitory concentration (MIC), a quantitative end point measurement of the concentration of crude leaf extracts (acidified 70\% acetone) and fractions of the 4 medicinal plants that halt microbial growth under visible threshold after 18 to $24 \mathrm{~h}$ were evaluated [38]. The assay was carried out by broth serial micro dilution assay using 96-well microtitre plate with p-iodonitrotetrazolium violet (INT) added as growth indicator [39].

For antibacterial test, bacterial cultures (Staphylococcus aureus, $2.6 \times 10^{12} \mathrm{cfu} / \mathrm{ml}$; Enterococcus faecalis, $1.5 \times$ $10^{10} \mathrm{cfu} / \mathrm{ml}$; Pseudomonas aeruginosa, $5.2 \times 10^{13} \mathrm{cfu} / \mathrm{ml}$; Escherichia coli, $3.0 \times 10^{11} \mathrm{cfu} / \mathrm{m}$ were sub-cultured from Mueller Hinton $(\mathrm{MH})$ agar plates with a $10 \%$ inoculum inMueller Hinton broth (MHB) (bacteria) was grown overnight. Microtitre plates were prepared by addition of
$100 \mu \mathrm{l}$ of distilled sterilized water to each well. A $100 \mu \mathrm{l}$ aliquot of the test samples at a starting concentration of $10 \mathrm{mg} / \mathrm{ml}$, positive controls (gentamicin) and negative control (acetone) were added to the first well followed by two fold serial dilutions. The final concentration of test samples was $2500 \mu \mathrm{g} / \mathrm{ml}$ (first well) and $19 \mu \mathrm{g} / \mathrm{ml}$ (last well). To each well, $100 \mu \mathrm{l}$ of the bacterial cultures was added. This 50\% inoculum ensyured there was no lag phase in the growth of the microorganism (39). The plates were airtight sealed and incubated at $37^{\circ} \mathrm{C}$ under $100 \%$ relative humidity conditions overnight. Thereafter, $40 \mu \mathrm{l}$ of $0.2 \mathrm{mg} / \mathrm{ml} \mathrm{INT} \mathrm{solution} \mathrm{was} \mathrm{added} \mathrm{to} \mathrm{all} \mathrm{inocu-}$ lated wells to determine growth inhibition of the microbes. The bacterial growth inhibitions were observed for $2 \mathrm{~h}$ at $30 \mathrm{~min}$ intervals after the addition of INT [39].

For antifungal test, fungal cultures (Candida albicans, $2.5 \times 10^{6} \mathrm{cfu} / \mathrm{ml}$; Aspergillus fumigatus, $8.1 \times 10^{6} \mathrm{cfu} / \mathrm{ml}$ and Cryptococcus neoformans, $2.6 \times 10^{6} \mathrm{cfu} / \mathrm{ml}$ ) were sub-cultured from Sabouraud agar plates and with a $10 \%$ inoculum in Sabouraud dextrose broth were grown overnight. The MICs determined using the serial dilution assay [40] with some modifications involving the addition of INT to the inoculated wells immediately because of the slower growth nature of fungi [41]. Amphoteric $\mathrm{B}$ and acetone were used as positive and negative control respectively. The plates were airtight sealed and incubated at $37^{\circ} \mathrm{C}$ for $36 \mathrm{~h}$ after which the fungal growth inhibitions observed for $6 \mathrm{~h}$ at $1 \mathrm{~h}$ intervals.

\section{Antioxidative assays}

2, 2-Diphenyl-1-picrylhydrazyl (DPPH) radical scavenging assay

The scavenging activity of crude extracts and fractions was assessed as described by Brand-Williams et al., [40] based on the reduction of methanolic DPPH in presence of a hydrogen donating antioxidant with some 
modifications to 96-well microtitre plate. DPPH, a deep violet coloured solution which has maximal absorption at $516 \mathrm{~nm}$ changes to yellow on reduction. The free radical scavenger activity of the compound is proportional to the colour change of DPPH. The methanolic solution of DPPH $(0.4 \mathrm{mg} / \mathrm{ml}, 160 \mu \mathrm{l})$ was dispensed from stock and added to $40 \mu \mathrm{l}$ ascorbic acid and trolox, 1.0-200 $\mu \mathrm{g} /$ $\mathrm{ml}$ (positive controls), different concentrations of crude extracts and fractions $(3.9-500 \mu \mathrm{g} / \mathrm{ml}$ ) or vehicle (an equivalent amount of methanol in the absence of substance test). Thirty minutes later the absorbance was measured at $516 \mathrm{~nm}$ using a Versamax microplate reader. The analysis was carried out in triplicate, and the results were expressed as percentage reduction of the initial $\mathrm{DPPH}$ absorption in relation to the control group. The concentration of extract that reduced DPPH colour by $50 \%\left(\mathrm{EC}_{50}\right)$ was determined.

\section{2, 2'-azinobis (3-ethylbenzthiazoline-6-sulphonic acid) (ABTS) radical scavenging assay}

The ABTS radical scavenging capacity of the samples was measured with modification to a 96-well microtitre plate format [42]. ABTS radical was generated by reacting $7 \mathrm{mM}$ solution of ABTS and $2.45 \mathrm{mM}$ solution of potassium persulfate at room temperature for $12 \mathrm{~h}$. The ABTS radical stock solution was adjusted to $7.00 \pm$ 0.02 at $734 \mathrm{~nm}$ before use. The test samples $(40 \mu \mathrm{l})$ were made in a concentration range of $0.3-250 \mu \mathrm{g} / \mathrm{ml}$ by two fold serial dilutions and $160 \mu \mathrm{l}$ of ABTS radical solution was added. Absorbance was measured after $6 \mathrm{~min}$ at $734 \mathrm{~nm}$. Trolox and ascorbic acid were used as positive controls, methanol as negative control and extract without ABTS as blank.

\section{Hydroxyl radical scavenging assay}

The hydroxyl radical scavenging activity of the extracts was determined with some modifications [43]. The hydroxyl radical was generated by using the Fenton reaction where $50 \mathrm{ml}$ of ferrous chloride $(8.0 \mathrm{mM}), 80 \mathrm{ml}$ of hydrogen peroxide and $50 \mathrm{ml}$ of distilled water, was allowed to stand for $1 \mathrm{~h}$. The mixture was filtered to remove the debris. Hydroxyl radical was determined by mixing $120 \mu \mathrm{l}$ of the hydroxyl radical solution with $66 \mu \mathrm{l}$ of the extracts followed by $14 \mu \mathrm{l}$ of salicylic acid $(20 \mathrm{mM})$. The mixture was incubated for $30 \mathrm{~min}$ at $37^{\circ} \mathrm{C}$ and absorbance read at $510 \mathrm{~nm}$.

\section{Linoleic acid peroxidation inhibitory assay}

The inhibition by the extracts of lipid peroxidation was determined according to the thiobarbituric acid method [44] with some modifications. The Fenton reaction $\left(\mathrm{Fe}^{2+}+\right.$ $\left.\mathrm{H}_{2} \mathrm{O}_{2} \rightarrow \mathrm{Fe}^{3+}+\mathrm{OH}^{*}\right)$ was used to induce the linoleic acid emulsion peroxidation [45]. In this assay, the aliquot contain $2.5 \mathrm{ml}$ of linoleic acid solution in methanol,
$150 \mu \mathrm{l}$ of TRIS $\mathrm{HCl}, 50 \mu \mathrm{l}$ of ascorbic acid, $500 \mu \mathrm{l}$ of extract $(8.0-250 \mu \mathrm{g} / \mathrm{ml})$ and $50 \mu \mathrm{l}$ of $\mathrm{FeSO}_{4}$. The mixture was incubated at $37^{\circ} \mathrm{C}$ for $60 \mathrm{~min}$ in the dark and the reaction was terminated by adding $516 \mu \mathrm{l}$ of $40 \%$ trichloroacetic acid dissolved in $0.01 \%$ sodium hydroxide solution. The MDA generated was measured by adding $1.6 \mathrm{ml}$ of thiobarbituric acid solution and the reaction mixture heated at $95^{\circ} \mathrm{C}$ for $15 \mathrm{~min}$. The absorbance was recorded at $510 \mathrm{~nm}$.

\section{Cytotoxicity assay of the crude extracts against Vero cell lines}

Cytotoxicity of the extract was determined by the MTT [3-(4, 5-dimethylthiazol-2-yl)-2, 5 diphenyltetrazolium bromide] assay [46] using a Vero African green monkey kidney cell line. The cells were cultured in Minimal Essential Medium (MEM) Earle's Base (Sigma), supplemented with $2 \mathrm{mM}$ L-glutamine, $16.5 \mathrm{mM} \mathrm{NaHCO}_{3}$ together with $0.1 \%$ gentamicin (Virbac) and $5 \%$ foetal calf serum (Sigma). Confluent monolayer culture suspensions of the cells were seeded into 96-well tissue culture microtitre plates at a density of $2 \times 10^{3}$ cells per well and incubated for $24 \mathrm{~h}$ at $37^{\circ} \mathrm{C}$ in a $5 \% \mathrm{CO}_{2}$ incubator. The MEM was removed from the cells, and extracts at various concentrations, positive control (berberine chloride (Sigma)) and negative controls were added and incubated for 5 days. The cells were observed using an inverted microscope to check for cytopathic effect from the extract. The cell proliferation and viability was quantified by addition of $30 \mu \mathrm{l}$ of a $5 \mathrm{mg} / \mathrm{ml}$ solution of MTT in PBS to each well and incubation for another $4 \mathrm{~h}$ at $37^{\circ} \mathrm{C}$. The medium was carefully removed from the wells without disturbing the MTT concentrate and washed twice with PBS. The liquid was aspirated from the cells and $50 \mu \mathrm{l}$ of DMSO was added to each well to dissolve the crystallized MTT formazan. The amount of reduced MTT was measured as absorbance at $570 \mathrm{~nm}$ using a Versamax microtitre plate reader. The results were expressed as a percentage growth of the control cells and $\mathrm{IC}_{50}$ values were calculated (Table 1).

\section{Phytochemical analysis}

Determination of total phenolic constituents of the extracts The total phenolic constituents of the extracts were determined using Folin-Ciocalteau method with some modifications [47]. The crude extracts $(50 \mu \mathrm{l})$ at concentration of 1:1 (mg:ml/w:v) plant material and extracting solvent was mixed with $500 \mu \mathrm{l}$ distilled water, $250 \mu \mathrm{l}$ of commercial Folin-Ciocalteau reagent diluted with distilled water (1:1) and $1250 \mu \mathrm{l}$ of $20 \%$ sodium carbonate solution. Absorbance of the mixture was recorded at $725 \mathrm{~nm}$ after incubation for $40 \mathrm{~min}$. The concentration of polyphenols (expressed as mg Gallic /g 
Table 1 Cytotoxicity of the acidified $70 \%$ acetone extracts

\begin{tabular}{llll}
\hline Test samples & Cytotoxicity $\left(\mathbf{I C}_{\mathbf{5 0}}(\boldsymbol{\mu} \mathbf{g} / \mathbf{m l})\right)$ & Lipid peroxidation inhibition $\left(\mathbf{L C}_{\mathbf{5 0}}(\boldsymbol{\mu} \mathbf{g} / \mathbf{m l})\right)$ & Lipoxygenase inhibition $\left(\mathbf{L L}_{\mathbf{5 0}}(\boldsymbol{\mu} \mathbf{g} / \mathbf{m l})\right.$ \\
\hline Maytenus peduncularis & $89.41 \pm 16.6$ & $39.84 \pm 5.52$ & $44.15 \pm 5.60$ \\
\hline Maytenus procumbens & $187.71 \pm 19.92$ & $34.21 \pm 1.63$ & $117.93 \pm 36.50$ \\
\hline Maytenus senegalensis & $87.62 \pm 3.02$ & $27.21 \pm 2.3$ & $115.80 \pm 20.11$ \\
\hline Maytenus undata & $99.17 \pm 11.88$ & $33.70 \pm 0.85$ & $50.92 \pm 25.70$ \\
\hline Berberine (positive control) & $4.74 \pm 0.41$ & &
\end{tabular}

dry weight) was calculated from a linear equation of the standard curve $(0.0019-0.25 \mathrm{mg} / \mathrm{ml}$ gallic acid) prepared at the same time using the following equation:

$$
\begin{aligned}
\text { Absorbance } & =4.9022 \times \mathrm{TP}(\mathrm{mg} \text { GAE }), \mathrm{R}^{2} \\
& =0.9804
\end{aligned}
$$

\section{Determination of total tannin content}

The total tannin content of the extracts was determined by using the polyvinylpyrrolidone (PVPP) binding method [47]. The tannin-binding mixtures were prepared by mixing $100 \mathrm{mg}$ of PVPP, $1.0 \mathrm{ml}$ of distilled water and $1.0 \mathrm{ml}$ of tannin-containing extracts in a centrifuge tube. The mixtures were thoroughly mixed by vortexing and kept at $4^{\circ} \mathrm{C}$ for $15 \mathrm{~min}$. The mixture was thawed and filtered using Whatman number 1 filter paper to remove the bound tannin. The filtrate $(100 \mu \mathrm{l})$ was dispensed into a test tube and the phenolic content determined as described above. Non-tannin phenolic composition was determined from the standard curve of catechin expressed as catechin equivalent in $\mathrm{mg} / \mathrm{g}$ dry material. The tannin content was calculated as the difference between the total phenolic and non-phenolic content of the extracts because the tannin was bound and precipitated by PVPP.

\section{Determination of proanthocyanidin content}

The proanthocyanidin content of the extracts was determined using the butanol- $\mathrm{HCl}$ assay [47]. The extract $(500 \mu \mathrm{l})$ was dispensed into a test tube and diluted to $10 \mathrm{ml}$ with $70 \%$ acetone. $3.0 \mathrm{ml}$ of $95 / 5 \mathrm{butanol} / \mathrm{HCl} \mathrm{re}-$ agent and $100 \mu \mathrm{l}$ of $2 \%$ ferric ammonium sulphate in $2 \mathrm{~N} \mathrm{HCl}$ were added. The test tubes were loosely covered and heated in a boiling water bath for $50 \mathrm{~min}$. The absorbance was recorded at $550 \mathrm{~nm}$ after the tubes and contents were cooled to room temperature. Absorbance of the unheated mixture was used as a blank.

\section{Determination of condensed tannin content}

The condensed tannin content of the extracts was determined using the vanillin/ $\mathrm{HCl}$ assay [48]. To $0.5 \mathrm{ml}$ of the extract measured into a test tube, $3 \mathrm{ml}$ of vanillin reagent containing $4 \%$ concentrated $\mathrm{HCl}$ and $0.5 \%$ of vanillin in methanol was added. The mixture was allowed to stand for $15 \mathrm{~min}$. The absorbance was recorded at $500 \mathrm{~nm}$ against methanol as a blank. The concentration of condensed tannin in the extracts expressed as catechin equivalent (CE)/g dry plant material was calculated using the following equation:

$$
\begin{aligned}
\text { Absorbance } & =0.1791 \times \mathrm{CT}(\mathrm{mg} \mathrm{CE})+0.0504, \mathrm{R}^{2} \\
& =0.9440 .
\end{aligned}
$$

\section{Determination of hydrolysable tannin (gallotannin)}

The gallotannin content of the extracts was determined with the potassium iodate assay [49]. To $3 \mathrm{ml}$ of the extract, $1 \mathrm{ml}$ of saturated solution of potassium iodate was added and allowed to stand at room temperature for $40 \mathrm{~min}$. The absorbance was read at $550 \mathrm{~nm}$. A standard curve was prepared using gallic acid under the same conditions as the extracts and results expressed as gallic acid equivalent (GAE)/g dry plant material was calculated using the following equation:

$$
\begin{aligned}
\text { Absorbance }= & 0.8264 \times \mathrm{GT}(\mathrm{mg} \mathrm{GAE}) \\
& +0.0392, \mathrm{R}^{2} \\
= & 0.9155 .
\end{aligned}
$$

\section{Determination of total flavonoids and flavonols}

The total flavonoid content of the extracts was determined by the aluminium chloride method with some modifications [50]. Briefly $100 \mu \mathrm{l}$ of the extract was mixed with $100 \mu \mathrm{l}$ of $20 \% \mathrm{AlCl}_{3}$ and two drops of glacial acetic acid. The mixture was diluted with methanol to $3000 \mu \mathrm{l}$. Absorbance was read at $415 \mathrm{~nm}$ after $40 \mathrm{~min}$. Blank samples were prepared with the extract without $\mathrm{AlCl}_{3}$. Standard curve was prepared using quercetin (3.9-500 $\mu \mathrm{g} / \mathrm{ml})$ in methanol under the same conditions. The concentration of flavonoids was expressed as $\mathrm{mg}$ quercetin equivalent/g of dry plant material was calculated using the following equation:

$$
\begin{aligned}
\text { Absorbance } & =0.9747 \times \mathrm{FT}(\mathrm{mg} \text { quercetin }), \mathrm{R}^{2} \\
& =0.9846
\end{aligned}
$$

The flavonol content of the extracts was determined by the aluminium chloride method [50] with some modifications. Extract $(1 \mathrm{ml})$ was mixed with $1 \mathrm{ml}$ of $20 \mathrm{mg} / \mathrm{ml}$ 
of $\mathrm{AlCl}_{3}$ and $3 \mathrm{ml}$ of $50 \mathrm{mg} / \mathrm{ml}$ of sodium acetate. A standard curve was prepared using quercetin (0.0019$0.0312 \mathrm{mg} / \mathrm{ml}$ ) in methanol under the same conditions. Absorbance was read at $440 \mathrm{~nm}$ after $2.5 \mathrm{~h}$. The concentration of flavonol was expressed as mg quercetin equivalent/g of dry plant material was calculated using the following equation:

$$
\begin{aligned}
\text { Absorbance } & =34.046 \times \mathrm{FLL}(\mathrm{mg} \text { quercetin }), \mathrm{R}^{2} \\
& =0.9853
\end{aligned}
$$

\section{Lipoxygenase inhibitory assay}

The soybean 15-lipoxygenase (LOX) enzyme inhibition was measured in borate buffer $(0.2 \mathrm{M}, \mathrm{pH}$ 9) by following the increase in absorbance at $234 \mathrm{~nm}$ from $30 \mathrm{~s}$ after addition of the enzyme, using linoleic acid $(134 \mu \mathrm{M})$ as substrate [51]. The final enzyme concentration was 200 $\mathrm{U} / \mathrm{ml}$. Test substances were added as DMSO solutions (final DMSO concentration of 1.6\%); DMSO alone was added in control experiments. The enzyme solution was kept on ice, and controls were measured at intervals throughout the experimental periods to ensure that the enzyme activity was constant. All measurements were carried out in triplicate for the controls and each concentration of the test samples. Quercetin was employed as a positive control. Calculation of enzyme activity was carried out [32], and $\mathrm{IC}_{50}$ values were determined by non-linear interpolation between the measuring points closest to $50 \%$ activity.

\section{Statistical Analysis}

All values were expressed as mean \pm SD. The sigmoidal dose-response (variable slope) best fit $\mathrm{EC}_{50}$ for each extract and fraction was computed with the associated standard error. The analysis was performed using GraphPad Prism for Windows, version 5.03 (GraphPad Software, San Diego, CA, USA). Statistical analysis of the results was performed by using one way ANOVA, followed by Bonferroni multiple comparison post hoc tests and the significant difference was set at $\mathrm{P}<0.05$.

\section{Results}

\section{Yield of extraction and fractionation}

The yield of the extracts and the fractions of various polarities using hexane, dichloromethane, ethyl acetate, butanol and residual water are presented in Figure 2. Maximum yield was obtained for the extracts of $M$. senegalensis $(37.89 \pm 3.05 \%)$ followed by $M$. undata $(36.89 \pm 4.775)$, while M. peduncularis $(33.12 \pm 1.07 \%)$ gave the lowest yield. The extraction process efficiently removed the chlorophyll from the bulk of the $70 \%$ acetone extract into the hexane portion. A part of the dried residual water fraction could not be redissolved due to the formation of insoluble complexes between the polyphenolics and other high molecular weight components such as polysaccharides.

\section{Antimicrobial activities of the crude extracts and fractions} The minimum inhibitory concentrations (MICs) of the four Maytenus phenolic-enriched crude extracts and fractions of various polarities against some enteric pathogens are presented in Table 2. All the crude extracts and fractions of various polarities have antimicrobial activities. Generally for all tested medicinal plants, the crude extracts and polar fractions (butanol and water) were less active than the non-polar fractions (hexane and dichloromethane) while the intermediate polar fraction (ethyl acetate) were moderately active. The hexane

Percentage yield of crude and fractions

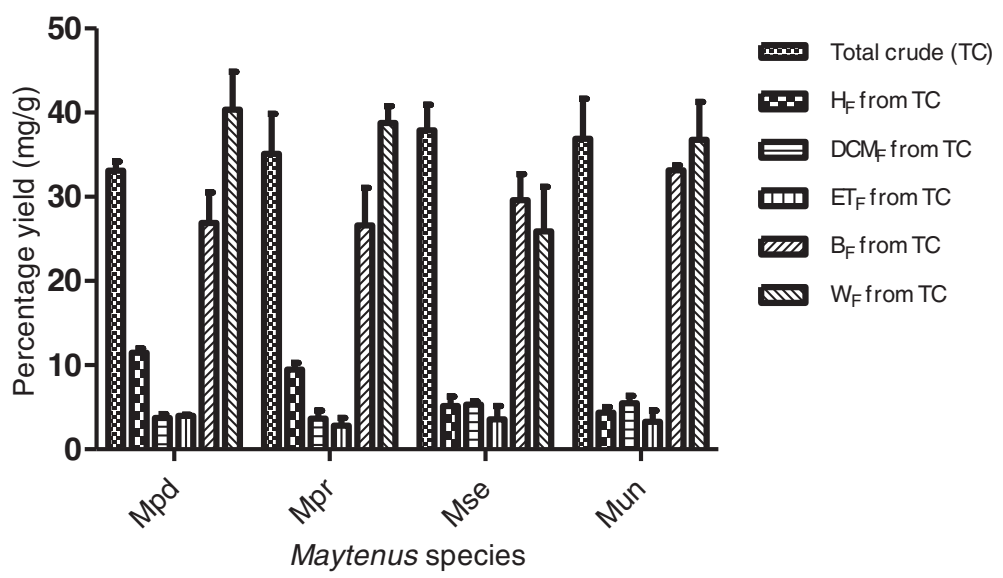

Figure 2 Yield of crude extract and fractions. Mpd = Maytenus peduncularis, Mpr = Maytenus procumbens, Mse = Maytenus senegalensis, Mun = Maytenus undata, $\mathrm{TC}=$ total crude, $\mathrm{H}_{\mathrm{F}}=$ hexane fraction, $\mathrm{DCM}_{\mathrm{F}}=$ dichloromethane, $\mathrm{ET}_{\mathrm{F}}=$ ethyl acetate, $\mathrm{B}_{\mathrm{F}}=$ butanol fraction, $\mathrm{W}_{\mathrm{F}}=$ water fraction. 
and dichloromethane fractions of $M$. senegalensis had good inhibitory activities the bacteria and fungi (MICs varying from 156 to $39 \mu \mathrm{g} / \mathrm{ml}$ ). All the bacteria were resistant to water fraction at the highest concentration tested but moderately sensitive to crude extract (MICs ranging from 312to $2500 \mu \mathrm{g} / \mathrm{ml}$ ) with $E$. coli and $E$. faecalis being the most resistant $(\mathrm{MIC}=2500 \mu \mathrm{g} / \mathrm{ml})$. The most susceptible bacteria were $P$. aeruginosa to crude extract $(625 \mu \mathrm{g} / \mathrm{ml})$, hexane $(39 \mu \mathrm{g} / \mathrm{ml})$, dichloromethane $(78 \mu \mathrm{g} / \mathrm{ml})$, ethyl acetate $(156 \mu \mathrm{g} / \mathrm{ml})$, Butanol $(1250 \mu \mathrm{g} / \mathrm{ml})$, and $S$. aureus to crude extract $(625 \mu \mathrm{g} / \mathrm{ml})$, hexane $(78 \mu \mathrm{g} / \mathrm{ml})$, dichloromethane $(39 \mu \mathrm{g} / \mathrm{ml})$, ethyl acetate $(156 \mu \mathrm{g} / \mathrm{ml})$, butanol $(625 \mu \mathrm{g} / \mathrm{ml})$.

The fungi were moderately sensitive to the crude extract (MICs ranging from 1250 to $156 \mu \mathrm{g} / \mathrm{ml}$ ). C. neoformans was the most sensitive fungus to dichloromethane, ethyl acetate, butanol (MICs $=78 \mu \mathrm{g} / \mathrm{ml}$ ), crude extract, and hexane $(\mathrm{MICs}=156 \mu \mathrm{g} / \mathrm{ml})$. The non-polar fractions of $M$. procumbens had the largest broad spectrum activities as they were active against all the microorganisms investigated with good MIC value (MIC $=39 \mu \mathrm{g} / \mathrm{ml})$. E. coli, E. faecalis, $P$. aeruginosa, $C$. albicans and $C$. neoformans ( $\mathrm{MIC}=$ $39 \mu \mathrm{g} / \mathrm{ml}$ ), and S. aureus and A. fumigatus (MIC $=78 \mu \mathrm{g} / \mathrm{ml}$ ) were the most sensitive to the dichloromethane fractions. The organisms were also very sensitive to hexane fractions (E. coli, E. faecalis, S. aureus, $(\mathrm{MIC}=39 \mu \mathrm{g} / \mathrm{ml})$, and $P$. aeruginosa and $A$. fumigatus ( $\mathrm{MIC}=78 \mu \mathrm{g} / \mathrm{ml})$ ), C. albicans and C. neoformans $(\mathrm{MIC}=156 \mu \mathrm{g} / \mathrm{ml})$, the crude extract, ethyl acetate and butanol fractions were moderately active (MIC ranging from 1250 to $156 \mu \mathrm{g} / \mathrm{ml}$ ) whereas the water fraction was less active (MIC ranging from 312 to $>2500 \mu \mathrm{g} / \mathrm{ml})$. M. peduncularis had the highest inhibitory activities obtained with its hexane and dichloromethane fractions on P. aeruginosa (MIC $=19 \mu \mathrm{g} / \mathrm{ml}$ ), and on $E$. coli and E. faecalis $(\mathrm{MIC}=39 \mu \mathrm{g} / \mathrm{ml})$. The dichloromethane fraction had a broad based spectrum of activity against all tested microorganisms (MICs varying from 156 to $19 \mu \mathrm{g} / \mathrm{ml}$ ) with $A$. fumigatus being the least sensitive $(\mathrm{MIC}=$

Table 2 Antibacterial and antifungal activities of the crude extracts and the fractions expressed as minimum inhibitory concentration $(\mu \mathrm{g} / \mathrm{ml})$

\begin{tabular}{|c|c|c|c|c|c|c|c|c|c|c|c|c|}
\hline \multirow[b]{2}{*}{ Microbial spp } & \multicolumn{6}{|c|}{ Maytenus peduncularis } & \multicolumn{6}{|c|}{ Maytenus procumbens } \\
\hline & $\mathrm{CrE}$ & Hex & DCM & ETOAC & But & Water & $\mathrm{CrE}$ & Hex & DCM & ETOAC & But & Water \\
\hline E. C & 312 & 39 & 39 & 78 & 625 & $>2500$ & 1250 & 39 & 39 & 156 & 1250 & $>2500$ \\
\hline E.f & 312 & 39 & 39 & 156 & 1250 & $>2500$ & $>2500$ & 39 & 39 & 156 & 625 & $>2500$ \\
\hline P. a & 312 & 19 & 19 & 156 & 312 & $>2500$ & 312 & 78 & 39 & 156 & 625 & $>2500$ \\
\hline S. a & $>2500$ & 78 & 39 & 312 & 78 & $>2500$ & 1250 & 39 & 78 & 312 & 625 & $>2500$ \\
\hline C. $a$ & 312 & 312 & 78 & 312 & 156 & 312 & 1250 & 156 & 39 & 156 & 312 & 625 \\
\hline C. $n$ & 78 & 312 & 78 & 78 & 1250 & 2500 & 625 & 156 & 39 & 156 & 156 & 2500 \\
\hline \multirow[t]{2}{*}{ A. $f$} & 312 & 78 & 156 & 156 & 312 & 625 & 1250 & 78 & 78 & 78 & 156 & 625 \\
\hline & \multicolumn{6}{|c|}{ Maytenus senegalensis } & \multicolumn{6}{|c|}{ Maytenus undata } \\
\hline Microbial spp & $\mathrm{CrE}$ & Hex & DCM & ETOAC & But & Water & CE & Hex & DCM & ETOAC & But & Water \\
\hline E. C & 2500 & 78 & 78 & 156 & 1250 & $>2500$ & 1250 & 312 & 156 & 156 & $>2500$ & $>2500$ \\
\hline E.f & 2500 & 39 & 39 & 312 & 625 & $>2500$ & 312 & 156 & 156 & 312 & 2500 & $>2500$ \\
\hline P. a & 625 & 39 & 78 & 156 & 1250 & $>2500$ & 312 & 78 & 78 & 78 & 2500 & $>2500$ \\
\hline S. a & 625 & 78 & 39 & 156 & 625 & $>2500$ & 625 & 156 & 156 & 156 & 312 & $>2500$ \\
\hline C. $a$ & 1250 & 78 & 39 & 156 & 156 & 625 & 1250 & 625 & 78 & 312 & 625 & 1250 \\
\hline C. $n$ & 156 & 156 & 39 & 78 & 78 & 1250 & 156 & 1250 & 78 & 78 & 312 & 2500 \\
\hline \multirow[t]{2}{*}{ A. $f$} & 625 & 156 & 78 & 156 & 1250 & 312 & 1250 & 625 & 625 & 156 & 625 & 625 \\
\hline & \multicolumn{12}{|c|}{ Controls } \\
\hline Microbial spp & Gent & Amp B & $70 \%$ ace & Distilled Water & & & & & & & & \\
\hline E. C & 0.39 & - & $>2500$ & $>2500$ & & & & & & & & \\
\hline E.f & 0.78 & - & $>2500$ & $>2500$ & & & & & & & & \\
\hline P. a & 1.56 & - & $>2500$ & $>2500$ & & & & & & & & \\
\hline S. a & 0.78 & - & $>2500$ & $>2500$ & & & & & & & & \\
\hline C. $a$ & - & 6.25 & $>2500$ & $>2500$ & & & & & & & & \\
\hline Microbial spp & Gent & Amp B & $70 \%$ ace & Distilled Water & & & & & & & & \\
\hline E. C & 0.39 & - & $>2500$ & $>2500$ & & & & & & & & \\
\hline
\end{tabular}

N.B: E. $\mathrm{c}=$ Escherichia coli, E. $\mathrm{f}=$ Enterococcus faecalis, P. $\mathrm{a}=$ Pseudomonas aeruginosa, $\mathrm{S} . \mathrm{a}=$ Staphylococcus aureus, C. $\mathrm{a}=$ Candida albicans, $\mathrm{C} . \mathrm{n}=$ Cryptococcus neoformans, $\mathrm{A}$. $\mathrm{f}=$ Aspergillus fumigatus, Gent = gentamicin, Amp B = amphotericin $\mathrm{B}, \mathrm{CrE}=$ crude extract, Hex $=$ hexane fraction, $\mathrm{DCM}=$ dichloromethane, $\mathrm{ETOAC}=$ ethyl acetate and But $=\mathrm{n}-$ Butanol. 
$156 \mu \mathrm{g} / \mathrm{ml})$. M. undata had the least inhibitory activity as all the microorganisms tested have some resistance to crude extracts and various fractions (MICs varying from $>2500$ to $312 \mu \mathrm{g} / \mathrm{ml}$ ) except $\mathrm{P}$. aeruginosa that was sensitive to hexane, dichloromethane, and ethyl acetate $(\mathrm{MIC}=78 \mu \mathrm{g} / \mathrm{ml})$, and C. neoformans to dichloromethane and ethyl acetate $(\mathrm{MIC}=78 \mu \mathrm{g} / \mathrm{ml})$. Acetone solution (70\%), used to dissolve the plant extracts did not have any inhibitory activity on the microbial growth.

\section{Antioxidant assays}

The phenolic-enriched extracts and fractions of various polarities from the leaves of four Maytenus species had strong antioxidant activities determined by the four different methods, namely the DPPH radical, ABTS radical, hydroxyl ion scavenging and linoleic acid peroxidation inhibitory activities Tables 3 and 1. For each sample, eight concentrations between 0.5 and $250 \mu \mathrm{g} / \mathrm{ml}$ were evaluated and the quantifications of the activities were expressed by calculating the $\mathrm{EC}_{50}$. The results indicated that the crude extracts of the four plant species have good $\mathrm{DPPH}$ scavenging capacity with $\mathrm{EC}_{50}$ values of $1.88 \pm 0.02,3.56 \pm 0.16,6.71 \pm 0.26$ and $3.48 \pm 0.09 \mu \mathrm{g} / \mathrm{ml}$ followed by ethyl acetate fractions with $\mathrm{EC}_{50}$ values of $2.33 \pm 0.21,1.22 \pm 0.15,9.50 \pm 0.11$ and $4.55 \pm 0.31 \mu \mathrm{g} / \mathrm{ml}$ for $M$. peduncularis, $M$. procumbens, $M$. senegalensis and $M$. undata respectively. Hexane and water fractions were inactive with $\mathrm{EC}_{50}$ values greater than $110.70 \pm$ 10.69 respectively for all the four plant species. The control compounds were trolox and ascorbic acid with $\mathrm{EC}_{50}$ values of. $1.18 \pm 0.06$ and $1.50 \pm 0.06 \mu \mathrm{g} / \mathrm{ml}$ respectively. For the ABTS radical decolourization, scavenging patterns were similar to that of $\mathrm{DPPH}$, although the $\mathrm{EC}_{50}$ values were comparatively lower in the ABTS assay for all corresponding test samples. Crude extracts of the four plants had good DPPH scavenging activity with $\mathrm{EC}_{50}$ values of $8.65 \pm 0.13,4.03 \pm 0.19,5.34 \pm 0.39$ and $7.89 \pm 0.31 \mu \mathrm{g} / \mathrm{ml}$ followed by ethyl acetate fractions with $\mathrm{EC}_{50}$ values of $6.34 \pm 0.18,1.71 \pm 0.13,3.59 \pm 0.06$ and $6.66 \pm 1.54 \mu \mathrm{g} / \mathrm{ml}$ for M. peduncularis, M. procumbens, $M$. senegalensis and $M$. undata respectively. For butanol fractions, the $\mathrm{EC}_{50}$ values were as follows: $52.79 \pm 14.44$, $8.89 \pm 2.86,7.78 \pm 3.13$, and $5.74 \pm 1.37 \mu \mathrm{g} / \mathrm{ml}$ for $M$. peduncularis, M. procumbens, $M$. senegalensis, and $M$. undata respectively. . The variation in the ABTS and DPPH radical scavenging activity of the butanol fractions may be due to differences in antiradical mechanisms. The efficiency of an antioxidant component to reduce DPPH largely based on a hydrogen atom mechanism while the ABTS assay is based on an electron transfer mechanism with faster reaction kinetics [52]. The radical scavenging activity of an extract depends on the quality of the active components rather than the quantity, especially the presence of hydroxyl groups and their position.

The scavenging capacities of the extracts on hydroxyl radical inhibition by the salicylic acid oxidation method expressed as $\mathrm{EC}_{50}$ are presented in Table 3. Crude extract of the four plants have good $\mathrm{OH}$ radical scavenging power with $\mathrm{EC}_{50}$ values of $23.92 \pm 2.29,107.69 \pm 12.32$, $146.30 \pm 21.60$ and $80.68 \pm 2.90 \mu \mathrm{g} / \mathrm{ml}$ followed by butanol fractions with $\mathrm{EC}_{50}$ values of $49.55 \pm 5.70,46.79 \pm$ $12.42, \quad 30.81 \pm 1.78$ and $51.19 \pm 5.30 \mu \mathrm{g} / \mathrm{ml}$ for $M$. peduncularis, $M$. procumbens, $M$. senegalensis and $M$. undata respectively. For ethyl acetate fractions, the $\mathrm{EC}_{50}$

Table 3 Free radical scavenging activities of the Maytenus species expressed as $\mathrm{EC}_{50}(\mu \mathrm{g} / \mathrm{ml})$

\begin{tabular}{|c|c|c|c|c|c|c|c|}
\hline \multirow[b]{2}{*}{ Assay } & \multicolumn{7}{|c|}{ Maytenus peduncularis } \\
\hline & Crude & Hex & DCM & ETOAC & But & Water & Trolox \\
\hline $\mathrm{DPPH}$ & $1.88 \pm 0.02$ & $113.13 \pm 12.63$ & $28.19 \pm 4.14$ & $2.33 \pm 0.21$ & $59.91 \pm 8.01$ & $153.40 \pm 20.62$ & $1.18 \pm 0.06$ \\
\hline ABTS & $8.65 \pm 0.13$ & $114.64 \pm 25.93$ & $33.54 \pm 1.29$ & $6.35 \pm 0.18$ & $52.79 \pm 14.44$ & $74.89 \pm 2.84$ & \\
\hline \multirow[t]{2}{*}{$\mathrm{OH}$} & $23.92 \pm 2.28$ & $110.54 \pm 17.91$ & $122.07 \pm 20.50$ & $70.86 \pm 18.09$ & $49.55 \pm 5.7$ & & \\
\hline & \multicolumn{7}{|c|}{ Maytenus procumbens } \\
\hline $\mathrm{DPPH}$ & $3.56 \pm 0.16$ & $110.70 \pm 10.69$ & $30.67 \pm 4.54$ & $1.22 \pm 0.15$ & $20.64 \pm 0.90$ & $189.00 \pm 7.56$ & $1.20 \pm 0.06$ \\
\hline ABTS & $4.03 \pm 0.19$ & $277.80 \pm 16.14$ & $22.26 \pm 1.36$ & $1.71 \pm 0.13$ & $8.99 \pm 2.86$ & $130.70 \pm 15.06$ & \\
\hline \multirow[t]{2}{*}{$\mathrm{OH}$} & $107.69 \pm 12.32$ & $179.70 \pm 41.17$ & $223.96 \pm 42.04$ & $76.70 \pm 11.58$ & $46.79 \pm 12.42$ & & \\
\hline & \multicolumn{7}{|c|}{ Maytenus senegalensis } \\
\hline $\mathrm{DPPH}$ & $6.71 \pm 0.26$ & $251.43 \pm 29.54$ & $121.27 \pm 10.99$ & $9.50 \pm 0.11$ & $48.10 \pm 0.26$ & $162.17 \pm 22.77$ & $1.28 \pm 0.07$ \\
\hline ABTS & $5.34 \pm 0.39$ & $312.75 \pm 43.83$ & $139.90 \pm 13.65$ & $3.59 \pm 0.06$ & $7.78 \pm 3.13$ & $62.86 \pm 3.97$ & \\
\hline \multirow[t]{2}{*}{$\overline{\mathrm{OH}}$} & $146.30 \pm 21.60$ & $187.40 \pm 55.56$ & $356.80 \pm 37.39$ & $42.06 \pm 12.90$ & $30.81 \pm 1.78$ & & \\
\hline & \multicolumn{7}{|c|}{ Maytenus undata } \\
\hline $\mathrm{DPPH}$ & $3.48 \pm 0.07$ & $160.50 \pm 31.40$ & $42.91 \pm 6.16$ & $4.55 \pm 0.31$ & $15.86 \pm 0.31$ & $607.30 \pm 7.57$ & $1.31 \pm 0.07$ \\
\hline ABTS & $7.89 \pm 0.31$ & $268.30 \pm 7.78$ & $55.30 \pm 5.09$ & $6.66 \pm 1.54$ & $5.74 \pm 1.37$ & $220.27 \pm 30.15$ & \\
\hline $\mathrm{OH}$ & $80.68 \pm 2.9$ & $284.36 \pm 27.04$ & $311.90 \pm 150.33$ & $155.53 \pm 35.85$ & $51.19 \pm 5.30$ & & \\
\hline
\end{tabular}

$\mathrm{CrE}=$ crude extract, $\mathrm{Hex}=$ hexane fraction, $\mathrm{DCM}=$ dichloromethane, ETOAc = ethyl acetate and But =n- Butanol, DPPH. = 2, 2-Diphenyl-1-picrylhydrazyl radical, $\mathrm{ABTS}=2,2$ '-azino-bis 3-ethylbenzothiazoline-6-sulfonic acid, $\mathrm{OH}=$ hydroxyl radical. 
values were as follows: $70.88 \pm 18.09,76.70 \pm 11.58,42.06 \pm$ 12.90 , and $155.53 \pm 35.85 \mu \mathrm{g} / \mathrm{ml}$ for $M$. peduncularis, $M$. procumbens, $M$. senegalensis, and $M$. undata respectively. All crude leaf extract of the four plant species led to dosedependent lipid peroxidation of linoleic acid induced by $\mathrm{FeSO}_{4}-\mathrm{H}_{2} \mathrm{O}_{2}$ system, which was monitored by the generation of malonydialdehyde MDA. The results expressed as $\mathrm{EC}_{50}$ are presented in Table 1. The $\mathrm{EC}_{50}$ values were $39.84 \pm 5.52,34.21 \pm 1.63,27.21 \pm 2.3$, and $33.70 \pm 0.85 \mu \mathrm{g} / \mathrm{ml}$ for $M$. peduncularis, M. procumbens, $M$. senegalensis, and $M$. undata respectively. $M$. senegalensis was the most active while $M$. peduncularis was the least active among the extracts.

\section{Cytotoxicity}

The cytotoxicity of the phenolic-enriched crude extracts of the four Maytenus species is presented in Table 1. The results indicate that the extracts are relatively nontoxic to Vero cell lines with $\mathrm{IC}_{50}$ values of $89.41 \pm 16.80$, $187.71 \pm 19.92,87.82 \pm 3.02$, and $99.17 \pm 11.88 \mu \mathrm{g} / \mathrm{ml}$ for $M$. peduncularis, $M$. procumbens, $M$. senegalensis, and $M$. undata respectively. In categorizing plant extract safety, $\mathrm{IC}_{50}$ values of $20 \mu \mathrm{g} / \mathrm{ml}$ and below were considered to be toxic [53]. Therefore, all the phenolicenriched extracts of the four Maytenus species showed no preliminary indication of toxicity although in vivo studies would need to confirm their safety for use in treating diarrhoea.

\section{Phenolic constituents}

The phenolic constituents of the crude extract of Maytenus species evaluated in this study varied widely as presented in Figure 3. The total phenolic content of the extracts ranged from $112.41 \pm 1.51$ to $197.44 \pm$ $2.68 \mathrm{mg} \mathrm{GAE} / \mathrm{g}$ plant material while the total tannin content ranged from $81.25 \pm 2.66$ to $1431.49 \mathrm{mg} \mathrm{GAE} / \mathrm{g}$ plant material. M. senegalensis contained the highest content of total phenolics (197.44 $\pm 2.68 \mathrm{mg}$ GAE/g dried plant material), total tannin $(143.10 \pm 1.49 \mathrm{mg}$ GAE/g dried plant material), condensed tannin (35.29 \pm $0.58)$, and proanthocyanidin $(54.33 \pm 2.01 \mathrm{mg}$. LE/g plant material) while $M$. procumbens contained the highest level of gallotannin $(12.59 \pm 3.80 \mathrm{mg} \mathrm{GAE} / \mathrm{g}$ dried plant material) and flavonol $(17.85 \pm 0.19 \mathrm{mg} Q E / g$ plant material). The flavonoid content was however highest in $M$. peduncularis (77.45 $\pm 1.43 \mathrm{mg} \mathrm{QE} / \mathrm{g}$ plant material). The enrichment of phenolic constituents in the extracts depends on the extracting solvent and the process of simultaneous extraction with acidified acetone solution and fractionation with $\mathrm{n}$-hexane was effective in this regard. The hexane probably removed all components such as chlorophyll, waxes and terpenoids from the water fraction efficiently. The statistical analyses of the phenolic constituents indicated the presence of a good correlation between DPPH radical scavenging ability and total phenolic $\left(\mathrm{R}^{2}=0.8826\right)$, non-tannin phenolic $\left(R^{2}=0.7110\right)$, total tannin $\left(R^{2}=0.9241\right)$ and proanthocyanidin $\left(R^{2}=0.6995\right)$ content. The same correlation was observed between the ABTS radical scavenging ability and total phenolic $\left(R^{2}=0.8768\right)$, nontannin phenolic $\left(R^{2}=0.7016\right)$, total tannin $\left(R^{2}=0.9189\right)$ and proanthocyanidin $\left(R^{2}=0.6792\right)$ content. On the other hand, a low correlation was obtained between gallotannin $\left(\mathrm{R}^{2}=0.2166\right)$, flavonoid $\left(\mathrm{R}^{2}=0.4555\right)$ and flavonol $\left(\mathrm{R}^{2}=0.3268\right)$ content and DPPH radical scavenging ability. A similar poor correlation was obtained between ABTS

Phenolic constituent of crude extracts

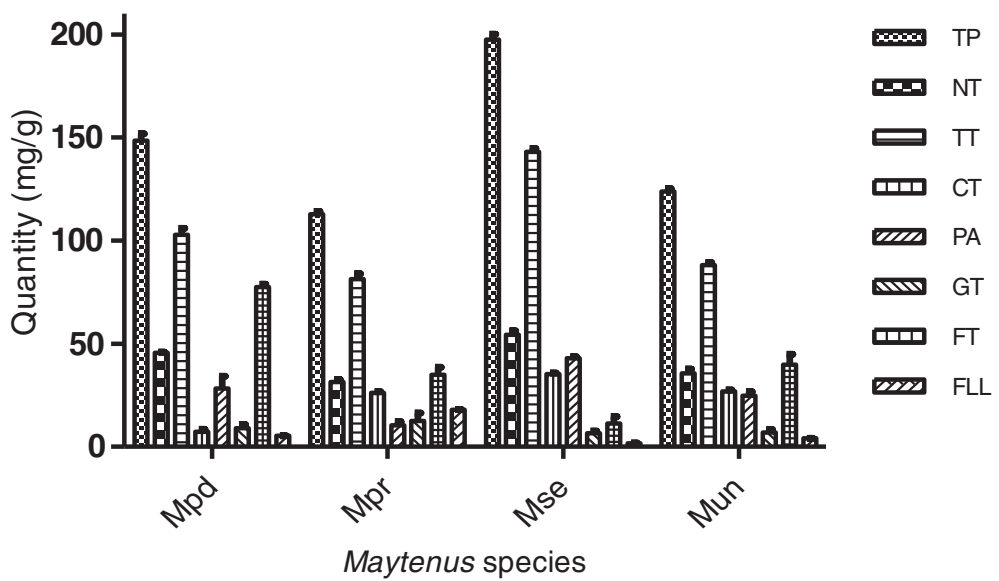

Figure 3 Phenolic compositions of the acidified $70 \%$ acetone leaf extracts. Mpd = Maytenus peduncularis, Mpr= Maytenus procumbens, Mse = Maytenus senegalensis, Mun = Maytenus undata, TP (Total phenolic (mg GAE/g)), TT (Total tannin (mg GAE/g)), NT (Non-tannin (mg GAE/g)), $\mathrm{CT}$ (Condensed tannin (mg CE/g)), PA (proanthocyanidin (mg LE)), GT (gallotannin (mg GAE/g)), FT (total flavonoid (mg QE/g)), FLL (flavonol (mg QE/g)). 
radical scavenging activity and gallotannin $\left(R^{2}=0.1997\right.$, flavonoid $\left(R^{2}=0.4632\right)$ and flavonol $\left(R^{2}=0.3014\right)$ content.

\section{Soybean 15-lipoxygenase inhibition}

The extracts of the four Maytenus species tested for in vitro inhibition of the enzyme soybean 15lipoxygenase had varying activity presented as $L_{50}$ and percentage inhibitions in Table 1 and Figure 4 respectively. The most active extract was obtained from M. peduncularis with $\mathrm{LL}_{50}$ value of $44.16 \pm 5.60 \mu \mathrm{g} / \mathrm{ml}$ followed by $M$. undata with $\mathrm{LL}_{50}$ of $50.92 \pm 25.70 \mu \mathrm{g} /$ $\mathrm{ml}$. The activity of the extracts was concentrationdependent and the percentage inhibition ranged from $61.55 \pm 4.19 \mu \mathrm{g} / \mathrm{ml}$ in $M$. peduncularis to $53.18 \pm$ $2.30 \mu \mathrm{g} / \mathrm{ml}$ in M. senegalensis at the highest concentration of $256 \mu \mathrm{g} / \mathrm{ml}$ and $42.15 \pm 4.29 \mu \mathrm{g} / \mathrm{ml}$ in $M$. peduncularis to $34.63 \pm 2.55 \mu \mathrm{g} / \mathrm{ml}$ in $M$. procumbens at the lowest concentration of $16 \mu \mathrm{g} / \mathrm{ml}$ of the extracts.

\section{Discussion}

Several therapeutic procedures have been used in orthodox medicine to treat diarrhoea symptoms, and associated complications. These include administration of oral rehydration therapy (ORT) as supportive therapy, use of antimicrobial drugs, anti-diarrhoeal agents (spasmolytic, motility, pro-absorptive or antisecretory) as symptomatic therapy and the use of probiotics (valuable in the treatment of rotavirus infections and post antibiotic diarrhoea) [54]. In traditional medicine, medicinal plants that contain a wide range of phytochemicals may exert an effect on more than one of the aspects listed above. The synergistic effects of the various medicinal properties may be responsible for the efficacy of plant preparations as antidiarrhoeal agents. However, the usefulness of medicinal plants in curing diarrhoea depends on the use of appropriate extractants. Two extractants such as water (decoction or infusion) and less frequently alcoholic solutions (tinctures) are mostly used in traditional medicines. Of equal importance is the dosage of the medicinal plant preparation administered to patients as applicable in conventional medicine.

Low MIC values indicate potentially high efficacy of the extracts as antimicrobial agents $[55,56]$. In our laboratory, crude extracts and fractions with an MIC $<100 \mu \mathrm{g} / \mathrm{ml}$ are usually regarded as pharmacologically interesting and promising material for further studies.

The fractionation procedure used in this study potentiated the antimicrobial activities of the leaf extracts in the hexane and dichloromethane fractions with MICs ranging from 39 to $156 \mu \mathrm{g} / \mathrm{ml}$ against all the organisms tested. The intermediate polarity fraction of ethyl acetate and butanol fraction had moderate antimicrobial activities with MICs ranging from 312 to $2500 \mu \mathrm{g} / \mathrm{ml}$. Crude extracts and water fractions had moderate to poor antimicrobial activities with MICs ranging from 312 to $2500 \mu \mathrm{g} / \mathrm{ml}$. However, some fractions had no microbial growth inhibition at the highest concentration of $2500 \mu \mathrm{g} / \mathrm{ml}$ used in this study.

Neither Gram negative nor Gram positive bacteria were highly sensitive to the crude extracts and residual

Lipoxygenase enzyme inhibition by the Maytenus species

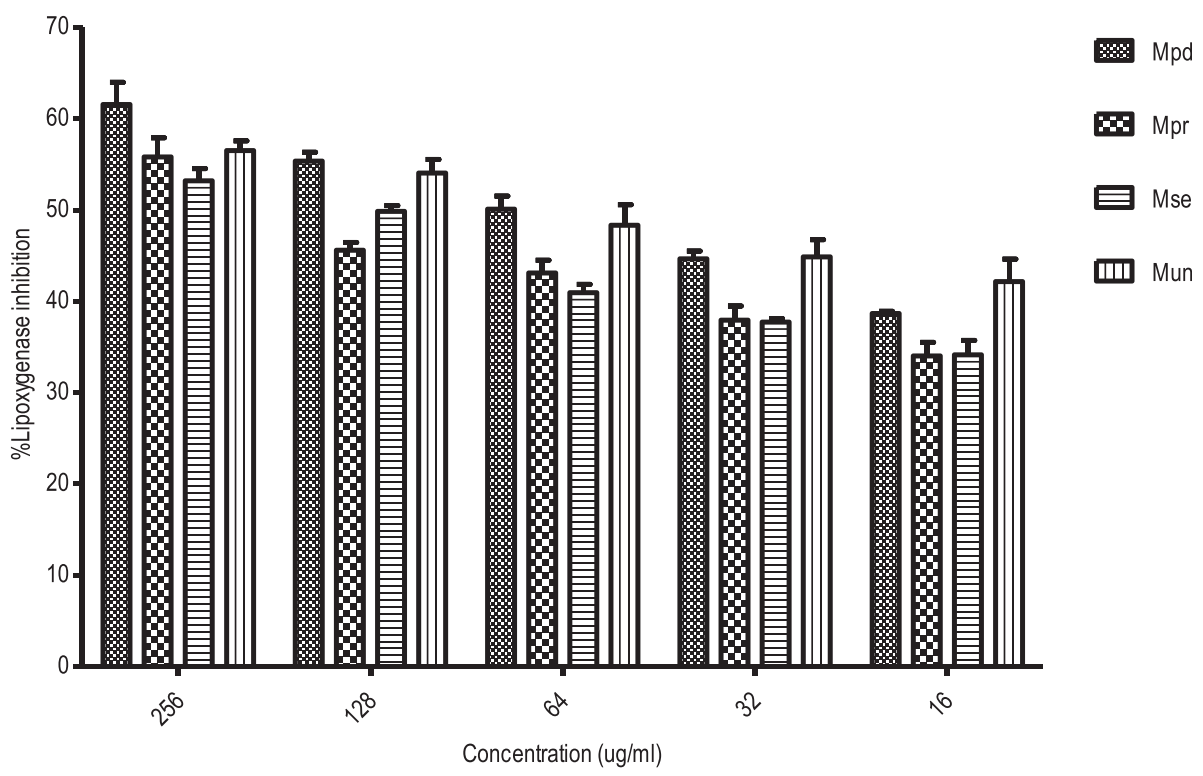

Figure 4 Concentration-dependent percentage inhibition of soybean 15-lipoxygenase enzyme. Mpd=Maytenus peduncularis, Mpr = Maytenus procumbens, Mse = Maytenus senegalensis, Mun = Maytenus undata. 
polar water fraction. This indicates that the antimicrobial compounds of Maytenus extracts are non-polar in nature. Therefore, in the treatment of infectious GIT including diarrhoea with leaf extracts of these plant species, the use of aqueous decoctions or infusions (polar extracts) which is the practice in traditional medicine may not be effective except where other antidiarrhoeal mechanisms are involved or if some nonpolar compounds were dissolved by microbial action during storage of concoctions. Absence of good antimicrobial activity from crude extracts and water fractions of all the four plants however, does not rule out the presence of such activity, but the phytoconstituents may be occurring in low ineffective concentrations. Many of the extracts and fractions were not highly active against microbes tested in this work. However, they may still be useful against infectious diseases since other mechanisms in healing process involving immuno-stimulatory $[57,58]$ and toxin-deactivating activities [59], molecular changes of compound from inactive to active may take place during the digestive process, and uptake and metabolism. Some antibiotics, such as macrolides, sulfonamides and tetracyclines, exert their pharmacological effect by inhibiting the logarithmic growth of the bacterial organism, letting the immune system fight the infection and relieving the symptoms [60]. The pharmacological effect is not always related either to a bactericidal or to a bacteriostatic effect, but could be due to the inactivation of bacterial virulence factors.

Antimicrobial, anti-inflammatory and cytotoxicity of ethanol root extracts of $M$. senegalensis have been reported [24,25]. Maytenonic acid (3-oxofriedelan-20 $\alpha$-oic acid) (antibacterial activity against Bacillus subtilus $(98 \mu \mathrm{g} / \mathrm{ml})$, Escherichia coli $(98 \mu \mathrm{g} / \mathrm{ml})$, Klebsiella pneumonia (98 $\mathrm{\mu g} / \mathrm{ml})$ and Staphylococcus aureus $(195 \mu \mathrm{g} / \mathrm{ml})$ ) [61] and pristimerin (antiplasmodial) [62] have been isolated from methanol root extract of $M$. senegalensis. Though this study did not establish the anti-infectious effect of leaf extracts from Maytenus species against all multitudes of microbes involve in GIT disorders, but they have demonstrated good potential as source of novel antimicrobial agents for the treatment of intestinal bacterial and fungal infections.

Oxidative stress and inflammatory damage of the GIT play an important role in initiating and maintaining diarrhoea symptoms. Oxidative species react with the mucosal epithelial membrane phospholipids to initiate and propagate the lipid peroxidation (LPO) process causing intestinal injury and cellular malfunction [63]. The products of lipid peroxidation include malondialdehydes, 4-hydroxyl-2, 3-nonenal, 4-hydroxy-2-hexenal and acrolein are cytotoxic [64]. In addition, the effects of LPO are also involved in the release of inflammatory mediators like cytokines, eicosanoids and generation of more reactive species [65]. Oxidative species such as hypochlorous acid, chloramine and some inflammatory mediators like prostaglandin $\mathrm{E}$ act directly as secretagogues in secretory or inflammatory diarrhoea [66]. An injured gastrointestinal tract (GIT) from lipid peroxidation also results in intestinal digestion and absorption disorders causing osmotic diarrhoea. Medicinal plants with good antioxidative or anti-inflammatory activities can be used as supportive therapy in diarrhoeal disease to reduce the oxidative damage to tissue cells.

The hexane, dichloromethane and water fractions had low antioxidant activities suggesting that their chemical components are extremely weak hydrogen or electron donors. However, antioxidant activities of the four plants were potentiated in the crude extracts, ethyl acetate and butanol fractions. Differences in antioxidant activity between the various solvents may due to variation in polyphenol concentration extracted. Different solvents have different degrees of solubility depending on their polarity [67].

Acetone and ethanol leaf extracts of $M$. procumbens have been reported to have anticancer and antioxidant properties. Two bioactive compounds, namely, 30-hydroxy-11amethoxy-18b-olean-12-en-3-one and asiatic acid have been isolated from the extract [22]. Radical scavenging activity potential of Maytenus species observed in this study was a promising outcome for possible control of many oxidative stress-related diseases. The leaf extracts from the four plants worked better as antiradical agents than as lipid peroxidation inhibitors, although high antioxidant activity was obtained using all the assays.

Almost all diseases are characterized by the inflammation and pain in response to different conditions like injuries and infection indicate the presence of cyclooxygenase and lipoxygenase (LOX). The lipoxygenase (LOX) inhibitory potential of the extracts of Maytenus species was determined using linoleic acid peroxidation to hydroperoxy linoleic acid (leukotriene (LT) catalysed by soybean 15-lipoxygenase enzymes. Although, the enzyme used is from a plant source, the activities are similar to arachidonic acid and mammalian 15-LOX as substrates. However, there can be some differences in primary structure and mechanistic pathways. LOXs are sensitive to antioxidants, and the common mechanism of action is inhibition of lipid hydroperoxide formation due to scavenging of lipid oxy- or 9-lipid peroxy-radicals formed in the course of enzyme peroxidation. This limits the availability of lipid hydroperoxide substrate necessary for the catalytic cycle of LOX [68]. Another mode of LOX inhibition is attained via chelation of its non-haem bound iron or by reduction of its ferric form [68].

Antimicrobial, anti-inflammatory, antioxidant and antimalarial activity of ethanol leaf extracts of Maytenus undata (Thunb.) have been reported $[23,69]$. Phytochemical 
studies of the ethanol leaf extract of Maytenus have led to isolation and characterization of a number of bioactive compounds with antistaphylococcal properties. The compounds include 3-oxo-11 $\alpha$-methoxyolean-12-ene-30-oic acid, 3-oxo-11 $\alpha$-hydroxyolean-12-ene-30-oic acid, 3-oxo-olean-9 (11),12-diene-30-oic acid, 3,4-seco-olean-4(23),12-diene-3,29dioic acid (20-epikoetjapic acid), 3,11-dioxoolean-12-ene-30oic acid (3-oxo-18 $\beta$-glycyrrhetinic acid), koetjapic acid, 12-oleanene artifact 3-oxo-11 $\alpha$-ethoxyolean-12-ene-30-oic acid [69]. The MICs of the compounds varied between 3.125-6.25 $\mu \mathrm{g} / \mathrm{ml}$ against methicillin-resistant S. aureus, S. aureus and P. aeruginosa [69].

Leukotrienes and other inflammatory mediators derived from LOX oxidation of polyunsaturated fatty acids (PUFA) are involved in intestinal smooth muscle lining contractions in diarrhoea and allergic reactions. The concentrationdependent inhibition of LOX by the phenolic-enriched Maytenus extracts indicated possible modulation of LT synthesis and therefore, the extracts can assist against diarrhoea through this mechanism.

For medicinal plant extracts to be useful in clinical application, the preparation should preferably be selectively toxic to the targeted organism or interfere directly with a specific reaction pathway. There should be no serious effect on the host cell or interference with normal physiological metabolism. The phenolic-rich Maytenus species extracts tested in this study were relatively non-toxic compared to the positive control (berberine chloride). However, in vivo acute toxicity studies are necessary to confirm the safety level of the extracts as in vitro assay results do not necessarily translate to in vivo activity. Effects of long term usage of the extracts such as mutagenicity and genotoxicity also need to be determined.

Phytochemical analyses of the crude extracts of the Maytenus species by other authors revealed the presence of varied quantities of phenolic compounds such as proanthocyanidins, flavonoids, flavonols and gallotannins. This group of compounds are important pharmacologically, being the antioxidant derivatives of medicinal and dietary plants. They also have other pharmacological activities such as antimicrobial (microbicidal or microbiostatic), antiinflammatory, antiviral, antidiarrhoeal [70], and immune modulatory activities. The phenolic-enriched crude extracts and the polar fractions of the Maytenus species tested in this study had good antioxidative activities in one or more of the antioxidant assays relevant to inflammation and diarrhoeal diseases. Therefore, the antioxidant activity of the polar fractions in combination with the potentiated antimicrobial activity of the non-polar fractions of the four Maytenus species may be useful as therapeutic agents against the broad spectrum of diarrhoeal mechanisms. The results of this study, therefore, give a scientific basis to the use of these plants in traditional medicine as antidiarrhoeal therapy.

\section{Conclusion}

The hexane, dichloromethane and ethyl acetate fractions had substantial antimicrobial activities against standard strains of diarrhoeagenic pathogens. The antimicrobial activities of these fractions coupled with the good antioxidative activities of the polar fractions in different oxidative mechanisms, especially diarrhoeic relevant lipid peroxidation and hydroxyl radical inhibition may provide relief in diarrhoea. These activities therefore provide a scientific base for the use of these plant species as antidiarrhoeal agents. The cytotoxicity assay results indicated that the extracts are relatively safe, but dosage still needs to be monitored in order to not exceed the toxicity level of the extracts. Other antidiarrhoeal mechanisms such as spasmolytic, antisecretory, antimotility and pro-absorption properties of the extracts may also have to be investigated so as to establish the actual mechanisms of action.

In many cases the ethyl acetate fraction had the highest antibacterial and antioxidant activities. If the safety of these fractions can be confirmed and there are no bioavailability or stability problems, these fractions may be developed into potentially useful therapeutic products to treat diarrhoea in production animals.

\section{Abbreviations \\ ABTS: 2,2' azinobis(3-ethylbenzthiazoline-6-sulphonic acid); ATCC: American type culture collection; CE: Catechin equivalent; CFU: Colony-forming units; CD4+: Count of CD4 expressing helper T; DMSO: Dimethylsulphoxide; DPPH: 1, 1-Diphenyl-2-picrylhydrazyl; GAE: Gallic acid equivalent; GIT: gastrointestinal tract; $1 C_{50}$ : Inhibitory concentration for $50 \%$ of maximum response; INT: p-iodonitrotetrazolium violet; $L_{5}$ : Lipoxygenase inhibitory concentration for $50 \%$ of maximum response; LE: Leucoproanthocyanidin equivalent; LOX: Lipoxygenase; LPO: Lipid peroxidation; MIC: Minimum inhibitory concentration; MTT: 3-(4, 5-dimethylthiazol-2-yl)-2, 5 diphenyltetrazolium bromide; OH: Hydroxyl; PVPP: polyvinylpyrrolidone; QE: Quercetin equivalent.}

\section{Competing interests}

The authors declare that they have no competing interests.

\section{Authors' contributions}

ASA participated in the study design, performed the experiments and data entry, analysed the results, and draft the manuscript. LJM participated in the study design, performed the cytotoxicity experiments and data entry, and critically reviewed the manuscript. JNE conceived and participated in the design of the study, reviewed the results, and critically reviewed the manuscript. All authors read and approved the final manuscript.

\section{Acknowledgement}

Ms Lita Pauw provided the plant material that she has collected from different National Botanical Gardens of the South African National Biodiversity Institute as part of her study. The South African Medical Research Council provided funding.

\section{Author details}

'Phytomedicine Programme, Department of Paraclinical Sciences, Faculty of Veterinary Science, University of Pretoria, Private Bag X04, Onderstepoort 0110, South Africa. ${ }^{2}$ Permanent address: Federal Institute of Industrial Research, Oshodi, P.M.B 21023, Ikeja, Lagos, Nigeria.

Received: 10 December 2012 Accepted: 10 May 2013 Published: 11 May 2013 


\section{References}

1. Schulzke J-D, Troger H, Amasheh M: Disorders of intestinal secretion and absorption. Best Practice \& Res Clin Gastroenter 2009, 23:395-406.

2. Sakunpak A, Panichayupakaranant P: Antibacterial activity of Thai edible plants against gastrointestinal pathogenic bacteria and isolation of a new broad spectrum antibacterial polyisoprenylated benzophenone, chamuangone. Food Chem 2012, 130:826-831.

3. Quigley EMM, Quera R: Small Intestinal Bacterial Overgrowth: Roles of Antibiotics, Prebiotics, and Probiotics. Gastroenter 2006, 130:S78-S90.

4. Kelly P: Infectious diarrhoea. Medicine 2011, 39(4):201-206.

5. Michelangeli F, Ruiz MC: Physiology and pathology of the gut in relation to viral diarrhoea. In Viral gastroenteritis. Edited by Desselberger U, Gray J. Amsterdam: Elservier Science BV; 2003:23-50.

6. Thapar N, Sanderson IR: Diarrhoea in children: an interface between developing and developed countries. Lancet 2004, 363:641-53.

7. Petri WA Jr, Miller M, Binder HJ, Levine MM, Dillingham R, Guerrant RL: Enteric infections, diarrhea, and their impact on function and development. J Clin Invest 2008, 118:1277-1290.

8. Cello JP, Day LW: Idiopathic AIDS enteropathy and treatment of gastrointestinal opportunistic pathogens. Gastroenter 2009, 136:1952-65.

9. WHO, World Health Report 2003: World Health Organization. Geneva, Switzerland: WHO Publications Office; 2003:1-50.

10. Pavlick KP, Laroux FS, Fuseler J, Wolf RE, Gray L, Hoffman J, Grisham MB: Role of reactive metabolites of oxygen and nitrogen in inflammatory bowel disease. Free Radic Biol Med 2002, 33(3):311-322.

11. Sebastian E, Winter SE, Keestra AM, Tsolis RM, Baumler AJ: The Blessings and Curses of Intestinal Inflammation. Cell Host Microbe 2010, 8:36-42.

12. Gorowara S, Sapru S, Ganguly NK: Role of intracellular second messengers and ROS in the pathophysiology of V. cholerae 0139 treated rabbit ileum. Biochim Biophys Acta 1998, 1407:21-30.

13. Grisham MB, Gaginella TS, von Ritter C, Tamai H, Be RM, Granger DN: Effects of neutrophil-derived oxidants on intestinal permeability, electrolyte transport, and epithelial cell viability. Inflammation 1990, 14:531-42.

14. Segui J, Gironella M, Sans M, Granell S, Gil F, Gimeno M: Superoxide dismutase ameliorates TNBS-induced colitis by reducing oxidative stress, adhesion molecule expression, and leukocyte recruitment into the inflamed intestine. J Leukoc Bio 2004, 76:537-44.

15. Anh NT, Cam PD, Dalsgaard A: Antimicrobial resistance of Shigella spp isolated from diarrhoeal patients between 1989 and 1998 in Vietnam. Southeast Asian J Tropical Medical Public Health 2001, 32:856-862.

16. Dimitrios PK, Russell EL: Antifungal drug resistance of pathogenic fungi. Lancet 2002, 359:1135-1144.

17. Periska T, Murad L, Decy S, Nunung M, Shinta K, Wasis S, Cyrus HS, Narain P, James RC, William KA, James HB, Andrew LC, Buhari AO: Antimicrobial resistance of bacterial pathogens associated with diarrhoeal patients in Indonesia. Amer J Tropical Medicine and Hygiene 2003, 68:666-670

18. Chambers JR, Gong J: The intestinal microbiota and its modulation for Salmonella control in chickens. Food Res Int 2011, 44:3149-3159.

19. Bhat RB, Jacobs TV: Traditional herbal medicine in Transkei. J Ethnopharmacol 1995, 48:7-12.

20. Watt JM, Breyer-Brandwijk MG: The Medicinal and Poisonous Plants of Southern and Eastern Africa. 2nd edition. London: Livingstone; 1962.

21. Gonzalez AG, Bazzocchi IL, Moujir L, Jimenez IA: Ethnobotanical uses of Celastraceae: Bioactive metabolites studies. Nat Prod Chem 2000, 23:649-738.

22. Momtaz S, Hussein AA, Ostad SN, Abdollahi M, Lall N: Growth inhibition and induction of apoptosis in human cancerous HeLa cells by Maytenus procumbens. Food Chem Toxicol 2013, 51:38-45.

23. Muthaura CN, Rukunga GM, Chabra SC, Mungai GM, Njagi ENM: Traditional phytotherapy of some remedies used in treatment of malaria in Meru district of Kenya. S Afr J Bot 2007, 73:402-411.

24. da Silva G, Tamia M, Rocha J, Serrona R, Gomes ET, Sepodea B, Silva O: In vivo Anti-inflammatory effect and toxicological screening of Maytenus heterophylla and Maytenus senegalensis extracts. Hum Exp Toxicol 2010, 30(7):693-700

25. Matu EN, van Staden J: Antibacterial and anti-inflammatory activity of some plants used for medical purposes in Kenya. J Ethnopharmacol 2003, 87:35-41.

26. Koné WM, Atindehou KK: Ethnobotanical inventory of medicinal plants used in traditional veterinary medicine in Northern Côte d'Ivoire (West Africa). S Afri J Bot 2008, 74:76-84.
27. McGaw LJ, Eloff JN: Ethnoveterinary use of Southern African plants and scientific evaluation of their medicinal properties. J Ethnopharmacol 2008, 119:559-574.

28. Naczk M, Shahidi F: Extraction and analysis of phenolics in food. J Chromatography A 2004, 1054:95-111.

29. Butler KM: Enterococcal Infection in Children. Seminar Pediat Infect Dis 2006, 17:128-139.

30. Balaban N, Rasooly A: Staphylococcal enterotoxins. Int J Food Microbiol 2000, 61:1-10

31. Nataro JP, Kaper JB: Diarrhoeagenic Escherichia coli. Clin Microbiol Rev $1998,11: 142-201$

32. Garbati MA, Alasmari FA, Al-Tannir MA, Tleyjeh IM: The role of combination antifungal therapy in the treatment of invasive aspergillosis: a systematic review. Int J Infect Dis 2012, 16:e76-e81.

33. Jose RJ, Brown JS: Opportunistic and fungal infections of the lung. Medicine 2012, 40(6):335-339.

34. Zipfel PF, Skerka C, Kupka D, Luo S: Immune escape of the human facultative pathogenic yeast Candida albicans: The many faces of the Candida Pra1 protein. Int J Med Microb 2011, 301:423-430.

35. Talwar P, Chakrabarti A, Chawla A, Mehta S, Walia BNS, Kumar L, Chugh KS: Fundal diarrhoea: Association of different fungi and seasonal variation in incidence. Mycopathologia 1990, 110:101-105.

36. Franquet T, Giménez A, Hidalgo A: Imaging of opportunistic fungal infections in immunocompromised patient. Eur J Radiol 2004, 51:130-138.

37. Goldenberg S, Price N: Opportunistic fungal lung infections. Medicine 2008, 36(6):295-299.

38. Othman M, Loh HS, Wiart C, Khoo TJ, Lim KH, Ting KN: Optimal methods for evaluating antimicrobial activities from plant extracts. J Microbiol Methods 2011, 84:161-166

39. Eloff JN: A sensitive and quick microplate method to determine the minimal inhibitory concentration of plant extracts for bacteria. Planta Med 1998, 64:711-713.

40. Brand-Williams W, Cuvelier ME, Berset C: Use of a free radical method to evaluate antioxidant activity. Lebensmittel Wissenschaftund Technologie 1995, 28:25-30.

41. Masoko P, Picard J, Eloff JN: The antifungal activities of twenty-four Southern Africa Combretum species (Combretaceae). S Afr J Bot 2007, 73:173-183

42. Re R, Pellegrini N, Proteggente A, Pannala A, Yang M, Rice-Evans C Antioxidant activity applying an improved ABTS radical cation decolourization assay. Free Radic Biol Med 1999, 26(9/10):1231-1237.

43. Smirnoff N, Cumbes OJ: Hydroxyl radical scavenging activity of compatible solutes. Phytochemistry 1999, 28:1057-1060.

44. Xanthopoulou MN, Fragopoulou E, Kalathara K, Nomikos T, Karantonis HC, Antonopoulou S: Antioxidant and anti-inflammatory activity of red and white wine extracts. Food Chem 2010, 120:665-672.

45. Xun S, Tian Jingdong T, Zhaonan Z, Xinyuan L: Chemiluminescence study on the peroxidation of linoleic acid initiated by the reaction of ferrous iron with hydrogen peroxide. Biophys Chem 1991, 40:161-167.

46. Mosmann T: Rapid colorimetric assay for cellular growth and survival: application to proliferation and cytotoxicity assays. J Immunol Methods 1983, 65:55-63.

47. Makkar HPS: Quantification of tannins in tree and foliage- a laboratory manual. The Netherland: Klumer Academic Press Dordrecht; 2003.

48. Heimler D, Vignolini P, Dini MD, Vincieri FF, Romani A: Antiradical activity and polyphenol composition of local Brassicaceae edible varieties. Food Chemy 2006, 99:464-469

49. Vermerris W, Nicholson R: Phenolic Compounds Biochemistry. New York: Publisher Springer; 2006:151-196.

50. Abdel-Hameed ESS: Total phenolic contents and free radical scavenging activity of certain Egyptian Ficus species leaf samples. Food Chem 2009, 114(4):1271-1277.

51. Lyckander IM, Malterud KE: Lipophilic flavonoids from Orthosiphon spicatus as inhibitors of 15-lipoxygenase. Acta Pharm Nord 1992, 4:159-166

52. Naik GH, Priyadarsini Kl, Hari M: Free radical scavenging reactions and phytochemical analysis of triphala, an ayurvedic formulation. Curr Sci 2006, 90:1100-1105.

53. Zirihi GN, Mambu L, Guede-Guina F, Bodo B, Grellier P: In vitro antiplasmodial activity and cytotoxicity of 33 West African plants used for treatment of malaria. J Ethnopharmacol 2005, 98:281-285. 
54. Marcos $L A$, Dupont HL: Advances in defining aetiology and new therapeutic approaches in acute diarrhea. J Infect 2007, 55:385-393.

55. Doughari JH, El-mahmood AM, Tyoyina I: Antimicrobial activity of leaf extracts of Senna obtusufolia L. Afr J Pharm Pharmacol 2008, 2:07-013.

56. Sharma A, Patel VK, Rawat S, Ramteke P, Verma R: Identification of antibacterial component of some Indian medicinal plants against Klebsiella pneumoniae. Int J Pharm Pharmaceut Sci 2010, 2:123-127.

57. Agarwal AK, Singh M, Gupta N, Saxena R, Puri A, Verma AK, Saxena RP, Dubey CB, Saxena KC: Management of giardiasis by an immunomodulatory herbal drug Pippali rassayana. J Ethnopharmacol 1994, 44:143-146.

58. Agrawal AK, Tripathi DM, Sahai R, Gupta N, Saxena RP, Puri A, Singh M, Misra RN, Dubey CB, Saxena KC: Management of giardiasis by a herbal drug 'Pippali rasayana': a clinical study. J Ethnopharmacol 1997, 56:233-236.

59. Chen JC, Chang YS, Wu SL, Chao DC, Chang CS, Li CC, Ho TY, Hsiang CY: Inhibition of Escherichia coli heat-labile enterotoxin-induced diarrhea by Chaenomeles speciosa. J Ethnopharmacol 2007, 113:233-239.

60. Bakker-Woudenberg IAJM, van Vianen W, van Soolingen D, Verbrugh HA van Agtmael MA: Antimycobacterial agents differ with respect to their bacteriostatic versus bactericidal activities in relation to time of exposure, mycobacterial growth phase, and their use in combination. Antimicrob Agents Chemother 2005, 49:2387-2398.

61. Lindsey KL, Budesinsky M, Kohout L, van Stade J: Antibacterial activity of maytenoic acid isolated from the root-bark of Maytenus senegalensis (Lam.) Exell. S Afr J Bot 2006, 72:473-477.

62. Khalid SA, Friedrichsen GM, Christensen SB, El Tahir A, Satti GM: Isolation and characterization of pristimerin as the antiplasmodial and antileishmanial agent of Maytenus senegalensis (Lam.) Exell. ARKIVOC 2007, ix:129-134.

63. Kakkar P, Mehrotra S, Viswanathan PN: Interrelation of active oxygen species, membrane damage and altered calcium functions. Molecular cell Biochem 1992, 111(1-2):11-15.

64. Esterbauer $\mathrm{H}$, Schaur RJ, Zollner $\mathrm{H}$ : Chemistry and biochemistry of 4-hydroxynonenal, malonaldehyde and related aldehydes. Free Radic Biol Med 1991, 11:81-128.

65. Stables MJ, Gilroy DW: Old and new generation lipid mediators in acute inflammation and resolution. Prog Lipid Res 2011, 50:35-51.

66. Gaginella ST, Kachur JF, Tamai H, Kershavarzian A: Reactive oxygen and Nitrogen metabolites as mediators of Secretory Diarrhea. Gastroenter 1995, 109:2019-2028.

67. Doughari JH: Antimicrobial activity of Tamarindus indica Linn. Trop J Pharmaceut Res 2006, 5:597-603.

68. Rackova L, Oblozinsky M, Kostalova D, Kettmann V, Bezakova L: Free radical scavenging activity and lipoxygenase inhibition of Mahonia aquifolium extract and isoquinoline alkaloids. J inflammation 2007, 4:15

69. Muhammed I, El-Sayed KA, Mossa JS, Al-Said MS, El-Feraly FS, Clark AM Hufford CD, Oh S, Mayer AMS: Bioactive 12-Olaenene triterpene and secotriterpene acids from Maytenus undata. J Nat Prod 2000, 63:605-610.

70. Bruins MJ, Cermak R, Kiers JL, van der Meulen J, van Amelsvoort JM, van Klinken BJ: In vivo and in vitro effects of tea extracts on enterotoxigenic Escherichia coli-induced intestinal fluid loss in animal models. J Paediat, Gastroenter Nutr 2006, 43:459-469.

doi:10.1186/1472-6882-13-100

Cite this article as: Ahmed et al:: Evaluation of pharmacological activities, cytotoxicity and phenolic composition of four Maytenus species used in southern African traditional medicine to treat intestinal infections and diarrhoeal diseases. BMC Complementary and Alternative Medicine 2013 13:100.

\section{Submit your next manuscript to BioMed Central and take full advantage of:}

- Convenient online submission

- Thorough peer review

- No space constraints or color figure charges

- Immediate publication on acceptance

- Inclusion in PubMed, CAS, Scopus and Google Scholar

- Research which is freely available for redistribution

Submit your manuscript at www.biomedcentral.com/submit
C Biomed Central 